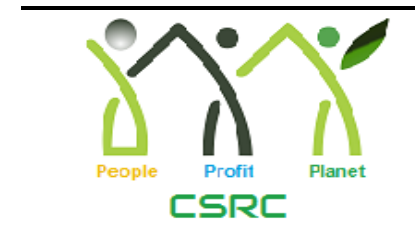

Volume and Issues Obtainable at Center for Sustainability Research and Consultancy

Journal of Business and Social Review in Emerging Economies

ISSN: 2519-089X (E): 2519-0326

Volume 6: Issue 3 September 2020

Journal homepage: www.publishing.globalcsrc.org/jbsee

\title{
Knowledge Management and Sustainable Firms Growth: An Evidence from SMEs Sector of Pakistan
}

\section{${ }^{1}$ Iftikhar Hussain, ${ }^{2}$ Ghulam Mujtaba Chaudhary, ${ }^{3}$ Adeel Arshad, ${ }^{4}$ Sabahat Akram}

${ }^{1}$ Associate Professor and Dean Faculty of Computing \& Engineering, University of Kotli Azad Jammu and Kashmir, Pakistan, iftikhar_raja@live.com

${ }^{2}$ Assistant Professor, Department of Business Administration, University of Kotli Azad Jammu and Kashmir,

Pakistan, ghulam.mujtaba@uokajk.edu.pk

${ }^{3}$ Lecturer, Department of Business Administration, University of Kotli Azad Jammu and Kashmir, Pakistan, adeelarshade@gmail.com

${ }^{4}$ Associate Professor and Treasurer, University of Kotli Azad Jammu and Kashmir, Pkaistan, sabahat_abrar@hotmail.com

\begin{tabular}{l} 
ARTICLE DETAILS \\
\hline History \\
Revised format: August 2020 \\
Available Online: September \\
2020
\end{tabular}

\section{Keywords}

Sustainable firms' growth,

Innovation, Knowledge

management, Product, Process,

SMEs

JEL Classification

$M 0, M 1$

\begin{abstract}
The main drive for this research was to investigate the relationship between knowledge management (KM) and sustainable firms' growth in SMEs sector of Pakistan. Moreover, the research examined the mediating role of product and process innovations on the association of knowledge management and sustainable firms' growth. A self-administered survey was structured and employed to gather the data from 218 garments related SMEs. The study employed SEM to measure direct and indirect effects. Findings of the study indicates that knowledge management has a positive and significant influence over sustainable firms' growth while both product and process innovations significantly mediated the knowledge management and sustainable firms growth relationship. Current research findings offer valuable implications concerning the importance of KM in enhancing and facilitating process and product innovations for sustainable firms' growth. This is a pioneer study for employing a unified model that illustrates the relationships among multiple variables pertaining to KM.
\end{abstract}

(C) 2020 Center for Sustainability Research and Consultancy Pakistan under a Creative Commons Attribution-NonCommercial-ShareAlike 4.0

\section{Corresponding author's email address: ghulam.mujtaba@uokajk.edu.pk}

Recommended citation: Hussain, I., Chaudhary, G. M., Arshad, A., \& Akram, S. (2020). Knowledge Management and Sustainable Firms Growth: An Evidence from SMEs Sector of Pakistan. Journal of Business and Social Review in Emerging Economies, 6(3), 1075-1086

\section{Introduction}

The volatile markets, unprecedented technological developments, and intense competition are affecting large manufacturing firms as well as SMEs. Rapidly changing customer needs and requirements, shortened product life cycles, advances in production and information technologies, free trade agreements and globalization are some of those factors which have contributed in this situation. Resultantly, small and medium enterprises (SMEs) are gradually stressed to improve their knowledge management related skills and abilities as well as improve their knowledge resources to be better able to enhance their sustainable growth and subsequently improve their competitiveness. In this regard, innovation and knowledge management are considered as two main options to 
meaningfully increase a firm's capability to successfully address the changing customers' needs and varying technologies with the purpose to move ahead in a turbulent business environment and maintain their growth and competitive advantage (Chang et al., 2012; Dahiyat, 2015).

The existing literature about knowledge management and firms growth investigates this relationship by focusing mainly on measuring growth with respect to competitiveness, organizational effectiveness, and market performance (Lee \& Lee, 2007; Lin \& Kuo, 2007). Apparently, a literature gap exists regarding the knowledge management and sustainable firms' growth link, specifically in garments sector SMEs. Sustainable firms growth is widely recognized measure for the efficiency and effectiveness of SMEs, and it replicates the ability to manage and employ knowledge resources for improving process and product innovation in these SMEs. Literature gap also exists concerning the role of process and product innovation in the relationship of knowledge management and sustainable firms growth (LópezNicolás \& Meroño-Cerdán, 2011).

The sustainable firms growth and innovation relationship was mostly recognized as unclear and is being considered as confusing and contradicting in prevailing literature and is creating the need to go for more studies measuring the relationships between different types of innovation, knowledge management and sustainable firm growth. Particularly, the impact of these types of innovations on knowledge management and sustainable firms' growth relationship in SMEs sector is still unexplored. Studies are also required to investigate the relationships among different types of innovation and sustainable firms growth (Damanpour \& Aravind, 2012). Work is needed to explore how knowledge management processes and capabilities of a firm effect the processes of product and process innovation needs to be investigated empirically (Abdallah et al., 2016). In the light of above discussion, this study plans to investigate and contribute in two ways. Firstly, by investigating empirically the direct impact of knowledge management on sustainable firms' growth and then measuring this impact through mediation of process and product innovations. Secondly, this study also explored the relationship of process and product innovation with sustainable firms' growth in SMEs.

\section{Literature Review}

\subsection{Knowledge Management}

Knowledge management can be seen as course of action, an ongoing process, an automation based infrastructure or a lifeline of present-day organizations, central to this is the knowledge which is the currency of management to manage valuable corporate resources and assets (Pauleen et al., 2007). Knowledge management is getting immense importance because of its critical role in knowledge economy, through reducing product manufacturing time as well as increasing operational excellence (Abdallah et al., 2016). Furthermore, in present day economy, organizations greatly depends on knowledge based resources and hence, knowledge management plays its part as it facilitates businesses to reduce their production cycle time, improve worker's efficiency and output, refine quality of manufactured items, add product features and also improve customer service, promotes collaborative novelty, renovate and reengineer business processes, provide quicker settlement of issues, promotes product and service offerings, thus focusing on continuous development of people and organizations (Al-Sa'di et al., 2017). Knowledge management also helps in achieving organizational goals by integration of resources, encouraging employees and allowing organizations for gaining advantage through effective teamwork and synergy in addition to sharing of knowledge and expertise (Mishra \& Bhaskar, 2011). Over and above ensuring informed decision making, it facilitates in sharing expertise and ultimately promotes collective perspectives ( López-Nicolás \& Meroño-Cerdán, 2011; Hussain et al., 2019).

\subsection{Product Innovation}

Product improvement is connected with opportunities of innovation through team-based work both in introducing knowledge entrenched products and services (Polder et al., 2010). Product innovation could include radical changes particularly in thinking process of making things happen. It may refer to incremental developing in product or organizational processes aimed at enhancing the quality of products and services. Polder et al. (2010) recognized the innovation process as a source to increase the value as each link to the chain needs to enhance quality of innovation in line with establishing high standards of competence. Product innovation can be achieved either by using new 
technologies or by an organized combination of ideas, information, and capabilities (Gunday et al., 2011).

Product innovation is a process of addressing issues relating quality and standards of products and services. It uses novel combination of ideas and resources aimed at improving the organizational growth as knowledge is the key in defining and bringing innovation and resolving the quality issues founded on well-built connection between organizational capabilities, core competencies and attaining firm growth. Although product innovation is an indispensable component of attaining firm growth but it is bit uncertain and remained much costly, as results depicts the hazardous situation, e.g. many projects could not be completed and ended in half way. Moreover, a very low rate of success has been seen pertaining to innovation management. It has been suggested that interdependent relationship among various components, such as employees, customers, management, and other externalities needs to be improved for successful innovation (Gunday et al., 2011).

\subsection{Process Innovation}

The basic purpose of innovation is to create and sustain value for businesses because it is only the innovation that can bring uniqueness in offerings, thus keeping the management alert about speedy changes in taste and preferences of customers. Organizations that uses process innovation aims at generating new products, and improving current status of products and services. Encouraging innovation is likely to open the doors for addressing problems and improvements in the quality in all facets of organizations (Al-Hakim \& Hassan, 2013). Process innovation may need implementation of entirely new methods which may have not been adopted previously (Karabulut, 2015). Gopalakrishnan and Damanpour (1994) revealed two key phases of process innovation, first is the act of applying knowledge and second is the alignment of opportunities with organizational capabilities. It was emphasized that initiation stage is distinguished by the readiness of management and employees to accept or oppose the innovation. Process innovation is strongly endorsed by leading authors in their scholarly writings and its importance is greatly highlighted in current literature as innovation process is key in achieving organizational growth and excellence. The phases of process innovation further add in identifying customer needs through open communication and innovation opportunities, via using a stepwise process to generate commercially feasible products. One more feature is the formation of a strong collaboration among inside and outside sources for better-quality output and for strategic and innovative moves (Hansen \& Birkinshaw, 2007). In innovation process, the approach that corporate world applies is thought to be the central part of the innovation aimed at smooth running of organizations and keeping them abreast with emerging trends. In any case, it is imperative to set up a useful controlling mechanism for evaluation of discrepancies. Due to malfunctioning, failures may occur in different phases while ensuring innovation happen (Tidd, 2014).

\subsection{Sustainable Firm Growth}

The issue of sustainability was originated more by the biological scientists than the management scientists, however, in today's competitive and challenging global environment many firms, managers, and management scientists are interested in sustainable firm growth. The phenomenon of firm growth sustainability is expanding due to dynamic market environment whereas corporate social responsibility and balanced scorecards are the two main source of practical support for this phenomenon (Kaplan \& Norton, 1996). Another important cause towards this phenomenon is the scarcity of organizational internal as well as external resources. The concept of measuring firm performance with respect to sustainability is catching attraction in all spheres of life (Sarrico \& Dyson, 2000).

The firm performance under the sustainability perspective can be measured at two different levels, i.e. firm level and inter-firms' level. At firm level, sustainable firm performance is measured through the decisions taken by the management and their impacts on firm's performance. At the inter-firm level, firm sustainable performance is measured by the decisions taken by the management and their impacts on overall industry (Bianchi, 2012). Measuring and evaluating the performance at firm level uphold a classic belvedere of sustainable growth. This point of view refers firm performance as a set of multiple variables, such as, increasing cash flows over the years, maintaining a reasonable increase in income, increase in total revenues over the years, and gradual increase in sales orders. Nevertheless, the immense competition in global as well as local markets and rapidly mounting dynamic complexity 
in social and economic system urge firms toward achieving inter-firm level sustainable performance. Achieving interfirm level sustainable performance means taking lead in maintaining horizontal or vertical strategic relationships with other firms in the same industry.

\section{Hypotheses Development}

\subsection{Knowledge Management and Product Innovation}

The significance of product innovation has remained the focus of modern literature, specifically when dealing with complex and dynamic market environment. The firms need to have a more efficient strategy for analyzing and developing the process of product innovation. In such a dynamic and competitive environment, knowledge management has assumed a vital role. Firms are striving hard to leverage their knowledge resources to ensure new and innovative products. Firms are trying to minimize space, time, and organizational limitations in order to overcome the problem of availability of knowledge resource where it is practically applied (Bartezzaghi et al., 1997). The management of todays' firms is trying to overcome such issues and create a synergy between knowledge management and product innovation to keep their firms innovative and competitive (Abbas et al., 2020; Wang \& Chen, 2020). Therefore, we can safely assume that:

H1. Knowledge management has a significant effect on product innovation.

\subsection{Knowledge Management and Process Innovation}

The business organizations assimilate information from external partners to enhance their innovation process. This, however, may hamper their process of developing new knowledge as well as linking old and new knowledge. Such situations demand the firms to activate their internal resources and capabilities for introducing such knowledge management practices which can improve the information and knowledge absorptive capacity of firm as well as instigate the process innovation. Many management researchers have defined knowledge management as a capability of leveraging firm internal as well as external knowledge to encourage innovation process, improve firm growth, and increase its products value (Du Plessis, 2007). Managing and practicing knowledge is very vital in current competitive and dynamic market environment as it enable firms to maximize value addition through leveraging internal and external knowledge sharing and facilitating teamwork for innovation. Knowledge management practices are for bringing and introducing process innovation in SMEs (Du Plessis, 2007; Hussain et al., 2015; Shujahat et al., 2019). Therefore, we can draw our hypothesis as:

$\mathrm{H} 2$. Knowledge management has a significant effect on process innovation.

\subsection{Knowledge Management and Sustainable Firm Growth}

Knowledge management in SMEs, specifically knowledge sharing, organizational learning, and shared experiences have a substantial impact on firm's ability to manage innovation and change as well as get competitive advantage and maintain its growth (Matlay et al., 2002; Cardoni et al., 2020). Some studies claims that firms are required to manage their knowledge in a systematic and sensible way in order to be competitive and achieve sustainable performance (Matlay et al., 2002; Phanayingphaisal \& Worawattanaparinya, 2020). These studies concludes that knowledge management focus and practices are a source of firm growth and development for a longer period of time. Matlay et al. (2002) recognized that only a smaller number firms can strategically manage their knowledge resources to sustain firm growth and get competitive advantage. These studies demonstrate that having a strategic perspective for managing and leveraging organizational knowledge is very important for ensuring firm survival as well as long term growth than any other factor. Based on this notion, it is hypothesized:

H3. Knowledge management has a significant direct effect on operational performance.

\subsection{Product Innovation and Sustainable Firm Growth}

The firms' ability to innovate and market their products and services are critically important to achieve sustainable firm growth and compete in a challenging environment (Sok et al., 2013). The firm's capability to innovate is an important determinant of firm growth. Some studies also pointed out that firms which are unable to innovate remains static (Atalay et al., 2013; Uhlaner et al., 2013). The firm's capabilities and resources are workable only when organized in combination (Kraiczy et al., 2015; Uhlaner et al., 2013). Thus, firms' need to gain resources and combine 
them with product innovation and promotional capabilities for long-term sustainable growth. H4. Product innovation has a significant effect on operational performance.

\subsection{Process Innovation and Sustainable Firm Growth}

A firm's capability for product innovation is defined as a set of interconnected practices and procedures employed for improving firm's existing products as well as developing new products. The capability of developing new processes is highly significant for SMEs to bring innovation and achieve sustainable growth (Bellucci et al., 2020; Cho \& Linderman, 2020). The researchers taken the perspective that process innovation empowers firms to sustain by introducing new products and services for meeting customers' needs and requirements, however for this firms are required to have process innovation capabilities. This perspective is based on an important ground, i.e. it is not necessary that a firm having superior resources will achieve growth. The more important component in this regard is the processes and capabilities to exploit these resources in effective manner (Kostopoulos et al., 2002). Based on these claims in literature, we have drawn following hypothesis:

H5. Process innovation has a significant effect on operational performance

\subsection{Mediating Relationships}

The contribution of knowledge management in achieving sustainable firm growth has been discussed in preceding section. Present research claims that the effect of knowledge management on firm's sustainable growth would be greater for those firms which are engaged in process and product innovation. This suggests that along with the direct relationship of knowledge management and firm sustainable growth, an indirect relationship via product and process innovation also exits. Such indirect impact is because of the actual exploitation of firm's assets (Lin \& Kuo, 2007). Successful knowledge management system enable the firms to introduce new, innovative, and efficient processes, and consequently these processes can reduce the firm's operational cost, increase quality, improves delivery and other services. According to Damanpour and Gopalakrishnan (2001), a firm's sustainable growth is improved through process innovation in two ways, i.e. upgrading manufacturing processes, and improving operational efficiency. Additionally, the resource-based view argues that process innovation based on firm knowledge generates such competitive advantages which cannot be meet by other firms (Wernerfelt, 1995). Knowledge management also strengthen firm's ability to innovate and resultantly improve firm's sustainable growth performance (Turulja \& Bajgoric, 2020).

The current competitive and dynamic global market urge firms to gradually increase their capabilities for responding to consumers and brining flexibility in their operations. These capabilities need managing organizational knowledge effectively, which then help in transforming the resources of a firm into organizational competencies and capabilities in the form of sustainable firm performance (Chang \& Ahn, 2005; Darroch, 2005). The process of knowledge management is a source of increasing creativity and innovation in processes and products, which may result in achieving sustainable firm growth. The improved innovation in processes can cause sustainable firm performance through upgrading existing manufacturing processes, enhancing efficiency and productivity of the firm operations, reducing operational costs, and introducing environmental friendly processes (Yang, 2010; López-Nicolás \& MeroñoCerdán, 2011). On the other hand, improved product innovation causes sustainable firm growth by bringing technological developments, creating new and innovative products, improving products quality and efficiency (Chang \& Ahn, 2005). In the light of these views, we proposed following mediating relationships for investigation.

H6. Knowledge management and sustainable firm growth relationship is positively mediated by the product innovation.

H7. Knowledge management and sustainable firm growth relationship is positively mediated by the process innovation.

\section{Materials and Methods}

\subsection{Sampling and Data Gathering}

This research is quantitative and causal in nature. A self-administered survey was used to collect data from 218 
garments sector firms operating in Faisalabad and Lahore. The sample was selected through stratified random sampling. The technique of stratified random sampling was employed because of its ability to minimize sample selection bias. This sampling technique also ensures accuracy through its characteristic of giving proper representation to each strata of the study's population. Executive managers, owners, manufacturing managers were taken as targeted population because of their direct involvement or interaction with all such processes.

\subsection{Research Model}

In current investigation, product and process innovations were hypothesized to mediate the association between knowledge management and sustainable firm growth. A constructive impact of KM on both kind of innovation as well as on sustainable firm growth was speculated. In addition, our conceptual model presumes a positive significant impact of product and process innovation on sustainable firm growth. The Resource-Based View of the firm was taken as underpinning theoretical base for proposed research model (Wernerfelt, 1995). Resource based view (theory) highlights the upshot of internal resources as key to sustain growth. This study is based on key question that KM competencies facilitate SMEs to launch excellent and unmatchable innovations that will noticeably increase sustainable firm growth. The proposed study model is illustrated in Figure 1 below.

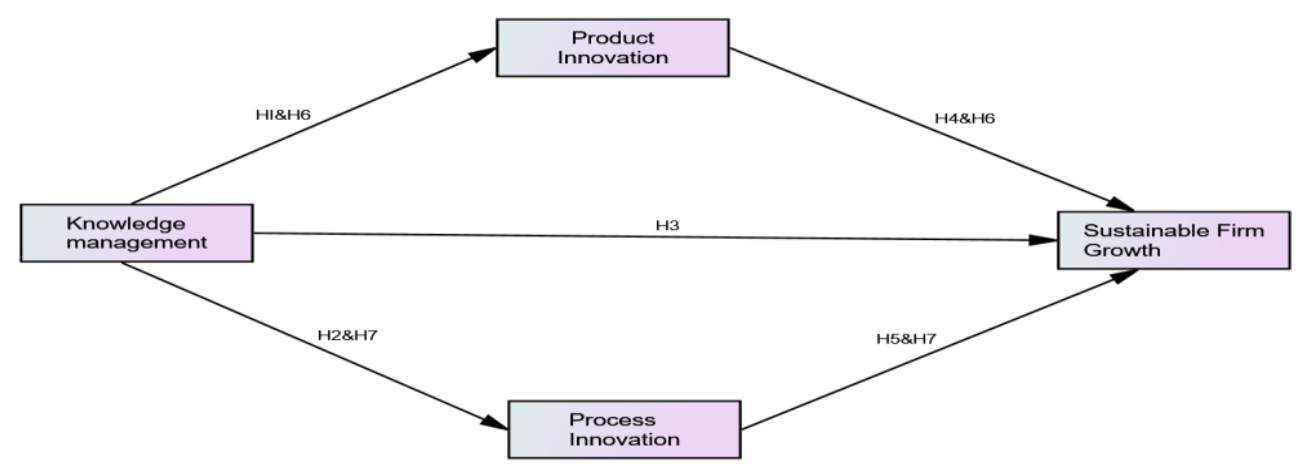

Figure 1. Research Model

\subsection{Measures}

Knowledge management was measured from four dimensions, i.e. creating new knowledge, sharing knowledge, storing and updating knowledge, and using knowledge. The scale was developed on the basis of some earlier studies (Lin \& Lee, 2005; Zack et al., 2009; Lee \& Wong, 2015; Al-Sa'di et al., 2017). Product innovation was determined in context of the efforts, which a firm may put in the process of developing new products or services in terms of persons, hours, teams, and training involved. Similarly, process innovation was taken in terms of changes introduced in the processes being used by a firm, efforts put into developing or introducing novel processes, and smart reply to innovative processes employed by the competing Firms. The measures of product and process innovation were adopted from some past studies (Manu, 1992; Atuahene-Gima, 2005; Jiménez-Jiménez \& Sanz-Valle, 2011; Al-Sa'di et al., 2017; Abbas et al., 2020). Sustainable firm growth was examined in terms of maintaining a reasonable increase in income, increase in total revenues over the years, gradual increase in sales orders, developing firm human capital, improving firm capacity, creating a better firm image in the minds of its stakeholders, contributing in development of a green and safe environment. The scale was adopted from the published studies of this domain (Fuller et al., 2008; Martin et al., 2013; Al-Sa'di et al., 2017).

\section{Results and Discussions}

\subsection{Structure Equation Modelling (SEM)}

For examining the hypothesized direct effects, structural equation modeling was applied and its results are reported in 
table 1.

Table 1. Direct effects

\begin{tabular}{cccccc}
\hline Hypothesis & Relationships & B & SE & t & p \\
\hline H1 & KM $\rightarrow$ PDI & 0.452 & 0.056 & 5.326 & $<0.01$ \\
H2 & $\mathrm{KM} \rightarrow$ PRI & 0.415 & 0.048 & 5.224 & $<0.01$ \\
\hline H3 & $\mathrm{KM} \rightarrow$ SFG & 0.647 & 0.045 & 8.332 & $<0.01$ \\
\hline H4 & PDI $\rightarrow$ SFG & 0.422 & 0.041 & 4.922 & $<0.01$ \\
\hline H5 & PRI $\rightarrow$ SFG & 0.398 & 0.062 & 4.886 & $<0.01$
\end{tabular}

Results in table 1 recognized the positive and significant impact of knowledge management on product innovation ( $\beta$ $=0.452, \mathrm{t}=5.326)$ and process innovation $(\beta=0.415, \mathrm{t}=5.224)$. These results supports our $\mathrm{H} 1$ and $\mathrm{H} 2$. Furthermore, the results indicates that knowledge management positively and significantly effects sustainable firm growth $(\beta=$ 0.647, $\mathrm{t}=8.332$ ), thereby supporting $\mathrm{H} 3$ of the study. Similarly, the results in table 1 also highlights that product innovation and process innovation have a positive and significant effect on sustainable firm growth, i.e. product innovation $(\beta=0.422, t=4.922)$, process innovation $(\beta=0.398, t=4.886)$. On the basis of these results, H4 and H5 were also supported and accepted. SEM path models are illustrated in figure 2 with the help of beta and $t$ values.

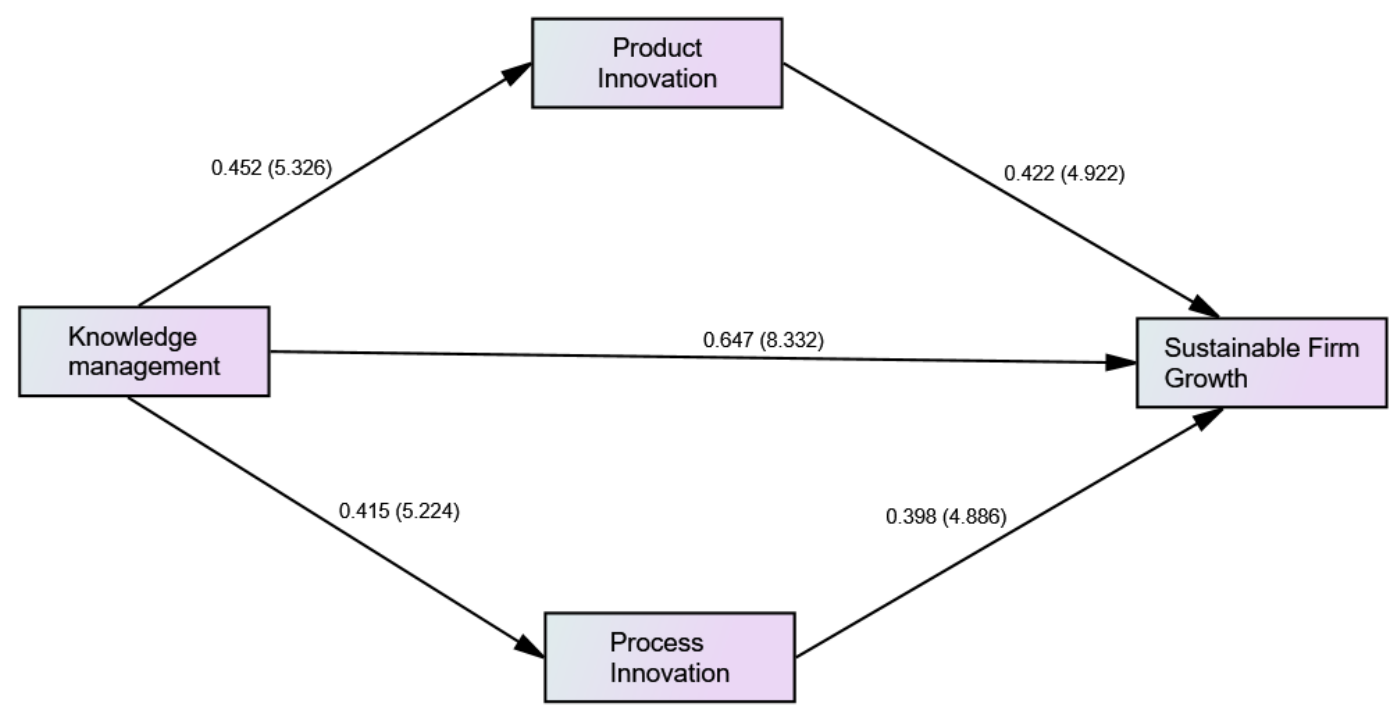

Figure 2. Structure Equation Modeling Paths

After establishing the direct effects, mediating mechanism was explored and its results are presented in table 2.

Table 2: Indirect Effects

\begin{tabular}{cccccccc}
\hline Hypothesis & Relationships & $\boldsymbol{\beta}$ & SE & $\mathbf{t}$ & $\mathbf{P}$ & LL & UL \\
\hline H6 & $\mathrm{KM} \rightarrow$ PDI $\rightarrow$ SFG & 0.312 & 0.048 & 5.864 & $<0.01$ & 0.168 & 0.378 \\
\hline H7 & $\mathrm{KM} \longrightarrow$ PRI $\rightarrow$ SFG & 0.264 & 0.032 & 4.121 & $<0.01$ & 0.146 & 0.342 \\
\hline
\end{tabular}


The results in table 2 reflects the indirect or mediation effects. The results indicates that the product innovation positively and significantly mediates the relationship between knowledge management and sustainable firm growth $(\beta$ $=0.312, \mathrm{t}=5.864, \mathrm{LL}=0.168, \mathrm{UL}=0.378)$, thus our $\mathrm{H} 6$ was accepted. The results also indicate that process innovation positively and significantly mediates the relationship between knowledge management and sustainable firm growth $(\beta=0.264 ; \mathrm{t}=4.121 ; \mathrm{LL}=0.146, \mathrm{UL}=0.342)$, therefore, $\mathrm{H} 7$ was also supported.

\section{Findings, Conclusions, and Implications}

The aim of present study was to examine the relationship between knowledge management, product innovation, process innovation, and sustainable growth of firms operating in garments sector of Pakistan. SEM was employed to test the hypothesize effects. Results of data analysis supported all the hypothesized relationships. Findings of the study highlighted a positive and significant interaction of knowledge management in designing, implementing, and managing process and product innovation as well as ensuring sustainable firm growth. The results related to H1 indicates that knowledge management has a positive and significant impact on product innovation. Many earlier studies supported these findings (Darroch, 2005; López-Nicolás \& Meroño-Cerdán, 2011). Similarly, results pertaining to $\mathrm{H} 2$ indicates that knowledge management has a positive and significant impact on process innovation of garments sector's firms and these findings were also supported by some earlier studies (Kraiczy et al., 2015; Obeidat et al., 2016). The results of current study further pointed out a positive and significant effect of knowledge management on sustainable firms' growth, proposed in H3. Many scholars have earlier confirmed these findings (Bogner \& Bansal, 2007; Chuang, 2004).

Findings of the study also depict a positive and significant impact of product and process innovation on sustainable growth of firms. These findings supported H4 and H5 and found consistent with some earlier studies of this domain (Guan \& Ma, 2003; Sezen \& Cankaya, 2013; Atalay et al., 2013). The results further supported H6 and H7 as it was found that both product innovation and process innovation positively and significantly mediates the relationship between knowledge management and sustainable firm growth. These findings are in line with some earlier studies ( Byukusenge et al., 2016; Al-Sa'di et al., 2017). Findings of the study implies that firms which are effectively managing the individual and organizational knowledge are more capable to maintain their growth for a relatively longer period. Findings also reflect that firms which are managing their knowledge resources more effectively are relatively successful in bringing innovation in organizational products and processes. The study concludes that the firms giving due importance and concentration to product and process innovations have relatively better long-term growth probabilities. Finally, findings of the study indicates that if the product and process innovations are successfully managed in a firm, it will act as a source of leveraging new knowledge as well as upgrade existing knowledge. In this way, it may indirectly increase the chances of a firm's sustainable growth.

The current study has significant theoretical contribution as it is based on resource-based view theory along with dynamic capability theory of the firm. The research highlights the practical implications of these two theories specifically for garments sector SMEs and for all other SMEs in general. Additionally, the current study is a valuable addition in literature about knowledge management and sustainable firm growth, as this was much lacking in exiting literature. Examining the mediation of product and process innovation in the association of knowledge management and sustainable firm growth is another important contribution of the current study. The success of any business depends upon its possession of knowledge resources, successful leveraging of these resources, and implementation of this knowledge in current processes and operations of the firm. The innovations, if given proper attention form managers and practitioners, can generate valuable outputs for organizations, helps them to be competitive, and ensure growth for a longer period (Qurashi et al., 2013). The present study is expected to be a valuable addition for managers and practitioners in SMEs sector. It will enable to analyze the current status of knowledge management in organizations, its implications in processes and operations, and to improve them accordingly for sustainable organizational growth. The study, however, employed a cross sectional design to examine the proposed relationships among the study variables. Future researchers are suggested to use longitudinal design in order to evaluate the model for an extensive time period. It is also suggested to add moderating variables, such as organizational culture and transformational leadership, in future studies. 


\section{References}

Abbas, J., Zhang, Q., Hussain, I., Akram, S., Afaq, A., \& Shad, M. A. (2020). Sustainable innovation in small medium enterprises: The impact of knowledge management on organizational innovation through a mediation analysis by using SEM approach. Sustainability, 12(6), 2407.

Abdallah, A. B., Phan, A. C., \& Matsui, Y. (2016). Investigating the effects of managerial and technological innovations on operational performance and customer satisfaction of manufacturing companies. International Journal of Business Innovation Research, 10(2-3), 153-183.

Al-Sa'di, A. F., Abdallah, A. B., \& Dahiyat, S. E. (2017). The mediating role of product and process innovations on the relationship between knowledge management and operational performance in manufacturing companies in Jordan. Business Process Management Journal, 23 (2), 349-376.

Al-Hakim, L. A. Y., \& Hassan, S. (2013). Knowledge management strategies, innovation, and organisational performance. Journal of Advances in Management Research, 1 (10), 58-71.

Atalay, M., Anafarta, N., \& Sarvan, F. (2013). The relationship between innovation and firm performance: An empirical evidence from Turkish automotive supplier industry. Procedia-Social Behavioral Sciences, 75(3), 226-235.

Atuahene-Gima, K. (2005). Resolving the capability: Rigidity paradox in new product innovation. Journal of Marketing, 69 (4), 61-83.

Bartezzaghi, E., Corso, M., \& Verganti, R. (1997). Continuous improvement and inter-project learning in new product development. International Journal of Technology Management, 14(1), 116-138.

Bellucci, M., Bini, L., \& Giunta, F. (2020). Implementing environmental sustainability engagement into business: sustainability management, innovation, and sustainable business models. In Innovation Strategies in Environmental Science (pp. 107-143): Elsevier.

Bianchi, C. (2012). Enhancing performance management and sustainable organizational growth through systemdynamics modelling. In Systemic Management for Intelligent Organizations (pp. 143-161): Springer.

Bogner, W. C., \& Bansal, P. (2007). Knowledge management as the basis of sustained high performance. Journal of Management studies, 44(1), 165-188.

Byukusenge, E., Munene, J., \& Orobia, L. (2016). Knowledge management and business performance: Mediating effect of innovation. Journal of Business Management Sciences, 4(4), 82-92.

Cardoni, A., Zanin, F., Corazza, G., \& Paradisi, A. (2020). Knowledge management and performance measurement systems for SMEs' economic sustainability. Sustainability, 12(7), 2594.

Chang, S. G., \& Ahn, J. H. (2005). Product and process knowledge in the performance-oriented knowledge management approach. Journal of Knowledge Management, 9(4), 114-132.

Chang, Y.-C., Linton, J. D., \& Chen, M.-N. (2012). Service regime: An empirical analysis of innovation patterns in service firms. Technological Forecasting Social Change, 79(9), 1569-1582. 
Cho, Y. S., \& Linderman, K. (2020). Resource-based product and process innovation model: Theory development and empirical validation. Sustainability, 12(3), 913.

Chuang, S.-H. (2004). A resource-based perspective on knowledge management capability and competitive advantage: An empirical investigation. Expert Systems with Applications, 27(3), 459-465.

Dahiyat, S. E. (2015). An integrated model of knowledge acquisition and innovation: Examining the mediation effects of knowledge integration and knowledge application. International Journal of Learning change, 8(2), 101135.

Damanpour, F., \& Aravind, D. (2012). Managerial innovation: Conceptions, processes, and antecedents. Management Organization Review, 8(2), 423-454.

Damanpour, F., \& Gopalakrishnan, S. (2001). The dynamics of the adoption of product and process innovations in organizations. Journal of Management studies, 38(1), 45-65.

Darroch, J. (2005). Knowledge management, innovation and firm performance. Journal of Knowledge Management, 9 (3), 101-115.

Du Plessis, M. (2007). The role of knowledge management in innovation. Journal of Knowledge Management, 11(4), 20-29.

Fuller, T., Warren, L., \& Argyle, P. (2008). Sustaining entrepreneurial business: A complexity perspective on processes that produce emergent practice. International Entrepreneurship and Management Journal, 4, 1-17.

Gopalakrishnan, S., \& Damanpour, F. (1994). Patterns of generation and adoption of innovation in organizations: Contingency models of innovation attributes. Journal of Engineering Technology Management, 11(2), 95-116.

Guan, J., \& Ma, N. (2003). Innovative capability and export performance of Chinese firms. Technovation, 23(9), 737747.

Gunday, G., Ulusoy, G., Kilic, K., \& Alpkan, L. (2011). Effects of innovation types on firm performance. International Journal of Production Economics, 133(2), 662-676.

Hansen, M. T., \& Birkinshaw, J. (2007). The innovation value chain. Harvard Business Review, 85(6), 121.

Hussain, I., Khan, A., Qurashi, A., Qurat-ul-Ain, \& Shabbir, A. (2015). The impact of knowledge sharing enablers on employees' performance: An empirical study on read foundation in Azad Jammu \& Kashmir. Journal of Information \& Knowledge Management, 14(03), 1550020.

Hussain, I., Qurashi, A., Mujtaba, G., Waseem, M. A., \& Iqbal, Z. (2019). Knowledge management: A roadmap for innovation in SMEs' sector of Azad Jammu \& Kashmir. Journal of Global Entrepreneurship Research, 9(1), 9.

Jiménez-Jiménez, D., \& Sanz-Valle, R. (2011). Innovation, organizational learning, and performance. Journal of Business Research, 64 (4), 408-417.

Kaplan, R. S., \& Norton, D. P. (1996). Linking the balanced scorecard to strategy. California Management Review, 39(1), 53-79. 
Karabulut, A. T. (2015). Effects of innovation types on performance of manufacturing firms in Turkey. ProcediaSocial Behavioral Sciences, 195, 1355-1364.

Kostopoulos, K. C., Spanos, Y. E., \& Prastacos, G. P. (2002). The resource-based view of the firm and innovation: identification of critical linkages. Paper presented at the 2nd European Academy of Management Conference.

Kraiczy, N. D., Hack, A., \& Kellermanns, F. W. (2015). The relationship between top management team innovation orientation and firm growth: The mediating role of firm innovativeness. International Journal of Innovation Management, 19(01), 1550005.

Lee, Y. C., \& Lee, S. K. (2007). Capabilities, processes, and performance of knowledge management: A structural approach. Human Factors Ergonomics in Manufacturing Service Industries, 17(1), 21-41.

Lee, C.S., \& Wong, K.Y. (2015). Development and validation of knowledge management performance measurement constructs for small and medium enterprises. Journal of Knowledge Management, 19 (4), 711-734.

Lin, C. Y., \& Kuo, T. H. (2007). The mediate effect of learning and knowledge on organizational performance. Industrial Management \& Data Systems, 107 (7), 1066-1083.

Lin, H.-F., \& Lee, G.-G. (2005). Impact of organizational learning and knowledge management factors on e-business adoption. Management Decision, 43 (2), 171-188.

López-Nicolás, C., \& Meroño-Cerdán, Á. L. (2011). Strategic knowledge management, innovation and performance. International Journal of Information Management, 31(6), 502-509.

Manu, F.A. (1992). Innovation orientation, environment and performance: A comparison of U.S. and European markets. Journal of International Business Studies, 23 (2), 333-359.

Martin, L., McNeill, T., \& Warren-Smith, I. (2013). Exploring business growth and eco innovation in rural small firms. International Journal of Entrepreneurial Behavior \& Research, 19 (6), 592-610.

Matlay, H., Mitra, J., \& Barr, P. (2002). Managing learning, knowledge and innovation in SMEs: An empirical approach. Management Research News, 25(8/10), 126-128.

Mishra, B., \& Bhaskar, A. U. (2011). Knowledge management process in two learning organisations. Journal of Knowledge Management, 15 (2), 344-359.

Obeidat, B. Y., Al-Suradi, M. M., \& Tarhini, A. (2016). The impact of knowledge management on innovation: An empirical study on Jordanian consultancy firms. Management Research Review, 39 (10), 1214-1238.

Pauleen, D. J., Corbitt, B., \& Yoong, P. (2007). Discovering and articulating what is not yet known: Using action learning and grounded theory as a knowledge management strategy. The Learning Organization, 14(3), 222240.

Phanayingphaisal, W., \& Worawattanaparinya, S. (2020). Effective management guidelines for industrial estate authority to support sustainable growth of the country. Academy of Strategic Management Journal, 19(1), 115.

Polder, M., Leeuwen, G. v., Mohnen, P., \& Raymond, W. (2010). Product, process and organizational innovation: drivers, complementarity and productivity effects. CIRANO-Scientific Publications, S-28. 
Qurashi, A., Hussain, I., Mushtaq, F., \& Ullah, A. (2013). The dilemma of success and failure in family business: Overcoming failure and attaining success. International Journal of Academic Research in Economics Management Sciences, 2(4), 161-177.

Sarrico, C. S., \& Dyson, R. G. (2000). Using DEA for planning in UK universities-an institutional perspective. Journal of the operational Research Society, 51(7), 789-800.

Sezen, B., \& Cankaya, S. Y. (2013). Effects of green manufacturing and eco-innovation on sustainability performance. Procedia-Social Behavioral Sciences, 99, 154-163.

Shujahat, M., Sousa, M. J., Hussain, S., Nawaz, F., Wang, M., \& Umer, M. (2019). Translating the impact of knowledge management processes into knowledge-based innovation: The neglected and mediating role of knowledge-worker productivity. Journal of Business Research, 94, 442-450.

Sok, P., O’Cass, A., \& Sok, K. M. (2013). Achieving superior SME performance: Overarching role of marketing, innovation, and learning capabilities. Australasian Marketing Journal, 21(3), 161-167.

Tidd, J. (2014). Conjoint innovation: Building a bridge between innovation and entrepreneurship. International Journal of Innovation Management, 18(01), 1450001.

Turulja, L., \& Bajgoric, N. (2020). Innovation as a mediator between knowledge management and organisational performance: Knowledge acquisition, knowledge application, and innovation towards the ability to adapt to change. In Knowledge Management, Innovation, and Entrepreneurship in a Changing World (pp. 46-68): IGI Global.

Uhlaner, L. M., van Stel, A., Duplat, V., \& Zhou, H. (2013). Disentangling the effects of organizational capabilities, innovation and firm size on SME sales growth. Small Business Economics, 41(3), 581-607.

Wang, F., \& Chen, K. (2020). Do product imitation and innovation require different patterns of organizational innovation? Evidence from Chinese firms. Journal of Business Research, 106, 60-74.

Wernerfelt, B. (1995). The resource-based view of the firm: Ten years after. Strategic Management Journal, 16(3), 171-174.

Yang, J. (2010). The knowledge management strategy and its effect on firm performance: A contingency analysis. International Journal of Production Economics, 125(2), 215-223.

Zack, M., McKeen, J., \& Singh, S. (2009). Knowledge management and organizational performance: an exploratory analysis. Journal of Knowledge Management, 13 (6), 392-409. 